\title{
Water loss in table grapes: model development and validation under dynamic storage conditions
}

\author{
Ericsem PEREIRA ${ }^{1 *}$, Renata Gonçalves Broco e SILVA ${ }^{1}$, Wigberto Antonio SPAGNOL ${ }^{1}$, Vivaldo SILVEIRA JUNIOR ${ }^{1}$
}

\begin{abstract}
Water loss is a critical problem affecting the quality of table grapes. Temperature and relative humidity (RH) are essential in this process. Although mathematical modelling can be applied to measure constant temperature and RH impacts, it is proved that variations in storage conditions are normally encountered in the cold chain. This study proposed a methodology to develop a weight loss model for table grapes and validate its predictions in non-constant conditions of a domestic refrigerator. Grapes were maintained under controlled conditions and the weight loss was measured to calibrate the model. The model described the water loss process adequately and the validation tests confirmed its predictive ability. Delayed cooling tests showed that estimated transpiration rates in subsequent continuous temperature treatment was not significantly influenced by prior exposure conditions, suggesting that this model may be useful to estimate the weight loss consequences of interruptions in the cold chain.
\end{abstract}

Keywords: moisture loss; fresh produce quality; predictive modelling.

Practical Application: Proposed water loss model was able to estimate changes in mass of grapes related to storage conditions.

\section{Introduction}

Fresh produce continuously lose water during the post-harvest handling. Relatively small moisture losses are enough to cause shriveling, wilting and undesirable texture changes (Kader, 2002). In addition, percent loss of fresh weight is used to describe freshness of horticultural products, since the loss of water decreases their economic value by reducing the saleable weight (Hertog et al., 2015; Shibairo et al., 2002). Table grape (Vitis Vinifera L.) is a nonclimacteric fruit very sensitive to temperature and humidity levels. Hence, storage at low temperature, around $0{ }^{\circ} \mathrm{C}$ (Fourie, 2008), and high levels of relative humidity (RH), around 95\% (Alferez et al., 2005), are recommended to maintain grapes in a good condition. The main table grapes post-harvest quality problems are decay caused by Botrytis cinerea, rachis desiccation and stem browning caused by water loss. Cumulative water losses also lead to berry shatter, wilting of the cluster and shriveling of the berries (Crisosto \& Mitchell, 2002). In some table grapes varieties water losses of 2 to $3 \%$, based on the initial weight, are sufficient to make stems show symptoms of browning (Crisosto et al., 1994). However, grape berries do not show symptoms of dehydration until the damage is quite evident in the stems. Losses in weight above $5 \%$ are necessary to wrinkles starts to appear in the berry skin (Nelson, 1978).

Liquid water moves across membranes of plant tissues and escapes to the air present in the intercellular spaces as water vapor. Indeed, the chemical potential of water in cells compared with that in the adjacent air determines the direction for net water movement occurring at cell-air interface (Nobel, 2005; Shamaila, 2005). Subsequently, the plant releases this water vapor into the surrounding atmosphere through a moisture transport known as epidermal transpiration (Maguire et al., 2001; Veraverbeke et al., 2003). Plant transpiration is affected by both fruit characteristics (e.g. surface-to-volume ratio, ripening stage) and climatic conditions (e.g. temperature, $\mathrm{RH}$ ). Transpiration rate was found to be better expressed in quantity of water loss per unit time per unit fresh weight (Leonardi et al., 1999).

Nevertheless, dealing with a homogeneous batch of particular specie the transpiration rate will be primarily controlled by the difference in water vapor pressure (WVP). Therefore, considering the air inside the plant material nearly saturated, the difference in WVP is determined solely by the temperature of the fruit, dry-bulb temperature and the humidity of the air (Thompson, 2002). Hence, the environmental conditions are essential in the water loss process.

Mathematical modelling has the ultimate goal of predicting future behavior of the products in any circumstances (Tijskens \& Schouten, 2009). Hence, modelling techniques has been applied to describe changes in the quality attributes of many fresh products (Amodio et al., 2013, 2015; Gwanpua et al., 2012, 2013; Hertog et al., 2004b, c; Schouten et al., 2007, 2010). In some of the reported works, the transpiration process was related to changes in texture attributes (Smedt et al., 2002) and visible wrinkling of the fruit skin (Hertog, 2002). However, even though the transpiration from fruit can be well described by the approach of steady state solution of Fick's first law, most of the publications on modelling this phenomenon consider constant temperature and $\mathrm{RH}$ during the storage time (Hertog et al., 2004a; Maguire et al., 1999; Mahajan et al., 2008). 
Nunes et al. (2009) demonstrated that variations in storage conditions are normally encountered in the cold chain and they have a huge effect on decreasing the quality and shelf life of grapes and other fresh products. However, some authors suggested that the weakest link of the cold chain is the domestic storage, while home refrigerators and freezers frequently present poor temperature control (James et al., 2008; Laguerre et al., 2002). A study performed by Gogou et al. (2015) for selected food products in Greece and France supports this argument, revealing that during the domestic storage temperatures may vary from $\sim 4{ }^{\circ} \mathrm{C}$ to $\sim 11^{\circ} \mathrm{C}$. In some cases the registered mean temperature was in a range of $8{ }^{\circ} \mathrm{C}$ to $10^{\circ} \mathrm{C}$.

In another relevant research, Lichter et al. (2011) found weight loss of gapes to be linear in constant conditions, but to our knowledge, there is no study about the weight loss profile of this fruit at home storage. Neither influence of dynamic storage conditions in its transpiration rate or validation of diffusional approach for variable scenarios was available yet.

According to the above literature review, no information is available about grapes transpiration rates and weight loss behavior under variable conditions of temperature and RH. So this study aimed proposing a methodology to develop a weight loss model for table grapes and validate its predictions in dynamic environment conditions of a common (domestic) refrigerator. Once cooling delays contribute in shortening the fruit market life (Crisosto et al., 2001; Johnston et al., 2005), the effect of waiting times was also studied by exposing fruit to cooling delays and comparing their transpiration rates to those of clusters stored under continuous refrigeration.

\section{Materials and methods}

\subsection{Material}

Table grapes (Vitis Vinifera L. cv. Crimson Seedless) were harvested, prepared and packed from a farm in Petrolina (PE, Brazil) in September and October 2016 on the commercial stage of maturity ( $17.8 \%$ and $20.5 \%$ in soluble solid content (SSC), respectively). In both seasons, only fruit without visible Botrytis infection and mechanical damage were packed in PET punnets $(185 \mathrm{~mm} \times 115 \mathrm{~mm} \times 90 \mathrm{~mm})$. The fruit were transported from the farm to the local supplier (Mape Frutas Agroindustrial, Jundiaí, SP, Brazil) in refrigerated truck. After the arrival at the local supplier, table grapes were purchased and transported to the laboratory at University of Campinas within $1 \mathrm{~h}$. All the samples were weighed using a weighing scale (AM 5500, Marte Cientifica, São Paulo, Brazil, with an accuracy of $0.01 \mathrm{~g}$ ) to get the initial mass (548.3 $\pm 14.2 \mathrm{~g}$ and $551.4 \pm 3.9 \mathrm{~g}$ in the first and in the second seasons, respectively).

\subsection{Experimental procedure}

The punnets were divided into 4 controlled temperature environments, which were formed by four refrigerators equipped with temperature controllers (N323TR, Novus Automation Inc., Porto Alegre, Brazil). The experiment was repeated twice with two different batches of table grapes and triplicates were used in both repetitions. Air temperature and relative humidity were measured inside the four storage containers. Table 1 shows the average and standard deviation (SD) of temperature and relative humidity levels used in the experiments for model building. Air temperature was measured with thin film temperature sensor elements Pt100 (CRZ-2005, Novus Automation Inc., Porto Alegre, Brazil), and the air relative humidity (RH) was measured with relative humidity and temperature transmitters (RHT-WM, Novus Automation Inc., Porto Alegre, Brazil).

In order to evaluate the weight loss profile, the mass of each sample was measured every two days for twenty nine days of experiment. A similar experimental setup was employed for both repetitions (fruit from September and October seasons). Cluster water loss was calculated as a percentage of its fresh (initial) weight. Subsequently, a transpiration model was used to fit the experimental data over time and to study the temperature and $\mathrm{RH}$ dependence of the transpiration rates.

\subsection{Development of the transpiration rate model}

The flow of water vapor through a fruit surface can be calculated according to the Fick's law of diffusion, which is proportional to the difference between humidity of fruit internal atmosphere and humidity of the surrounding air (Ben-Yehoshua, 1987). Equation 1 developed for calculating the transpiration rate of mushrooms (Mahajan et al., 2008), was used to calculate the amount of water loss from the plant per unit weight per unit time.

$T R=k_{i} \times\left(a_{w_{i}}-a_{w}\right) \times(1-\exp (-a T))$

Where $T R$ is the transpiration rate $\left(\mathrm{g} \mathrm{h}^{-1} \mathrm{~kg}^{-1}\right)$, expressed as a function of temperature and $\mathrm{RH} ; k_{i}$ is the mass transfer coefficient; $a w_{i}$ is the determined average water activity of the grapes $(0.977 \pm 0.0006)$; $a w$ is the water activity of the container $(\mathrm{RH} / 100) ; a$ is a coefficient constant; $T$ is the temperature $\left({ }^{\circ} \mathrm{C}\right)$.

Sousa-Gallagher et al. (2013) have combined Equation 1 with a technique reported by Leonardi et al. (1999), Equation 2, to evaluate transpiration rate related to weight loss, resulting in Equation 3.

$T R=M_{i}-M / t\left(M_{i} / 1000\right)$

$M=M_{i}-k_{i} \times\left(a_{w_{i}}-a_{w}\right) \times(1-\exp (-a T)) \times\left(M_{i} / 1000\right) t$

where $M$ and $M_{i}$ are the weight and the initial weight (g), respectively; $t$ is the time (h).

Table 1. Average and standard deviation $( \pm \mathrm{SD})$ of temperature and relative humidity levels used in the two repetitions (R) of the experiment for model building.

\begin{tabular}{|c|c|c|c|c|}
\hline \multirow{2}{*}{$\begin{array}{l}\text { Storage } \\
\text { condition }\end{array}$} & \multicolumn{2}{|c|}{ R1 } & \multicolumn{2}{|c|}{ R2 } \\
\hline & $\begin{array}{c}\text { Temperature } \\
\left({ }^{\circ} \mathrm{C}\right)\end{array}$ & $\begin{array}{l}\text { RH } \\
(\%)\end{array}$ & $\begin{array}{c}\text { Temperature } \\
\left({ }^{\circ} \mathrm{C}\right)\end{array}$ & $\begin{array}{l}\mathrm{RH} \\
(\%)\end{array}$ \\
\hline SC1 & $2.5 \pm 1.6$ & $45.9 \pm 6.4$ & $2.3 \pm 1.7$ & $49.5 \pm 12.1$ \\
\hline $\mathrm{SC} 2$ & $5.7 \pm 1.7$ & $43.8 \pm 4.6$ & $5.5 \pm 1$ & $51.2 \pm 9.4$ \\
\hline $\mathrm{SC} 3$ & $11 \pm 1.4$ & $54.2 \pm 9.9$ & $10.1 \pm 0.9$ & $50.1 \pm 10.1$ \\
\hline $\mathrm{SC} 4$ & $15.1 \pm 1.1$ & $66.2 \pm 4.5$ & $16.4 \pm 0.5$ & $65 \pm 5$ \\
\hline
\end{tabular}


Grapes transpiration data obtained for all the combinations of temperature and RH described in Table 1 was used to estimate the values of constants $k_{i}$ and $a$. Equation 2 was fitted by non-linear regression analysis using a Statistica software (Statsoft, 2007) to estimate the model parameters.

\section{Dynamic conditions model}

Total weight loss from a plant tissue is the integral of rates of weight loss at any particular time over the period following harvest (Maguire et al., 2001). As argued by Labuza (1982), given a historic of the storage conditions, it is possible to divide the whole period in small intervals $(t)$ in which these storage conditions are considered constant. Meanwhile, a generic phenomenon depending on environmental conditions also occurs at constant rates. Similarly, provided the rates of weight loss for each stage of the historic of a fruit, it is possible to calculate the total weight loss as the summation of the constant rates.

Based in those aspects, the following model in Equation 4 was proposed to predict the weight of grapes based on the fact that the initial weight is decreased by the sum of weight loss for each time interval. In those time intervals, measured temperature $\left(T_{j}\right)$ and container water activity $\left(a w_{j}\right)$ was considered constant. Additionally, the parameter $k i$ and $a$ were considered constant throughout the time intervals.

$$
M=M_{i}-\sum_{0}^{j=n} k_{i} \times\left(a_{w_{i}}-a_{w_{j}}\right) \times\left(1-\exp \left(-a T_{j}\right)\right) \times\left(M_{i} / 1000\right) t_{j}
$$

\section{Validation of the model}

In order to evaluate the reliability of Equation 4 for dynamic conditions, several relevant experiments were conducted in triplicate. The experimental setup was repeated twice in two different batches of table grapes cv. 'Crimson Seedless'. Punnets containing the clusters were stored in common domestic refrigerator (CRM30, Whirlpool S.A., São Paulo, Brazil) undergoing fluctuating temperatures (mean temperature $8.2 \pm 1.5^{\circ} \mathrm{C}$ and $5.1 \pm 2.9^{\circ} \mathrm{C}$, for first and second repetitions, respectively). A data logger system (Field Logger Register V2.2x B, Novus Automation Inc., Porto Alegre, Brazil) was employed to collect the measurements of the temperature and $\mathrm{RH}$ sensors, building the historic of these climatic conditions during the experiment period. Intervals of $1 \mathrm{~min}$ between measurements were used to build the historic of both temperature and $\mathrm{RH}$. Weight loss of the stored grapes was measured periodically for nineteen days and the experimental data compared with model predictions.

\subsection{Cooling delay trials}

Apart from the punnets stored under continuously refrigeration to estimate the model parameters, some samples were held for different time periods $(24,48,72 \mathrm{~h})$ at $25.1 \pm 2{ }^{\circ} \mathrm{C}$ and $45.3 \pm 8.9 \%$ $\mathrm{RH}$ to simulate environment conditions of temperature abuse during cooling delays. The experiments were conducted in triplicates for each waiting time period. After those periods, the samples were transferred to low temperatures $\left(0.9-4.1^{\circ} \mathrm{C}\right.$ and $\left.\sim 45 \% \mathrm{RH}\right)$.

During waiting time trials, the grape punnets were weighed daily to evaluate the transpiration rates (TR) by using Equation 2.
These rates were compared to those of fruit maintained in continuous refrigeration. Thus, this study determines the effect of cooling delays on subsequent transpiration rates.

\section{Results and discussion}

\subsection{Grapes transpiration rate}

Figure 1 shows the weight loss of grapes during storage at approximately $50 \% \mathrm{RH}$ in three different temperatures (SC1-R2, SC2-R2 and SC3-R2). Grapes mass decreased constantly with time at all combinations of temperature and RH. For similar relative humidity, fruit maintained at low temperature $\left(2.3^{\circ} \mathrm{C}\right)$ lost weight slower than those stored at higher one $\left(10.1^{\circ} \mathrm{C}\right)$. The transpiration rates of fruit in higher temperatures were accelerated by increasing the vapor pressure deficit and the respiration rates of the stems. This results support the ones reported by Lichter et al. (2011), which also found a linear profile for the mass decreasing in grapes of cultivars 'Thompson' and 'Superior'. This linear profile indicates a direct proportionality between the amount of mass loss and the storage time. Both temperature and humidity impact the transpiration rate in fruit, as have been seen for strawberries (Sousa-Gallagher et al., 2013) and mushrooms (Mahajan et al., 2008). In grape clusters, the most sensitive part to moisture diffusivity and dehydration is the stem. Its respiration rate is multiple times higher than the berry respiration (Mencarelli et al., 2005). Subsequently, increasing temperature can increase the transpiration rate of the clusters by accelerating the metabolic respiration of the stems and shifting the vapor pressure difference between fruit surface and the air.

Fitting Equation 1 to experimental data for each experimental condition (Table 1), TR was accurately calculated. Values ranged from 0.104 to $0.201 \mathrm{~g} \mathrm{~kg}^{-1} \mathrm{~h}^{-1}$ over all the combinations of temperature and humidity tested. This small range was found due to the strict levels of RH $(\sim 50 \%-65 \%)$ and temperature tested $\left(2-16^{\circ} \mathrm{C}\right)$. As mentioned by Tijskens et al. (2010), since the water loss is a generic process, i.e., the same model formulation and the same rate constant for all the individuals, the variations

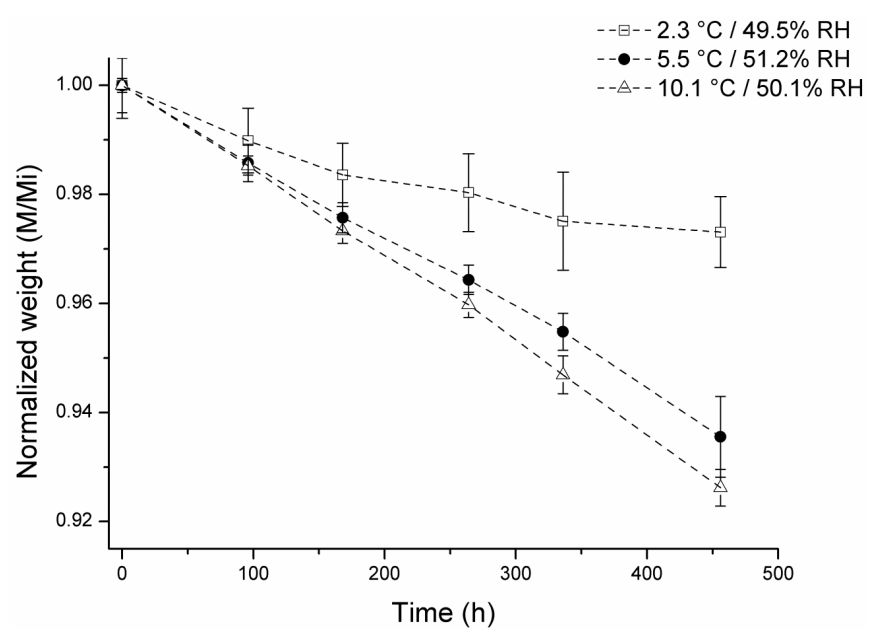

Figure 1. Changes in weight of grapes (M) over time (h). The values were normalized with respect to the initial weight of grapes (Mi). Each point of the curve corresponds to the average of three samples. Standard deviations are shown in error bars. 
in the transpiration rates are attributed to the effect of the storage conditions.

\subsection{Development of the transpiration model}

Experimental data obtained at all combinations of constant temperature and $\mathrm{RH}$ reported in section 2.1 were used to estimate constant coefficients $\left(k_{i}\right.$ and $\left.a\right)$ of the mathematical model (Equation 3). Their values were estimated using non-linear regression by Statistica software. Estimates and standard errors (SE) yielded by the regression are shown in Table 2 . Figure $2 \mathrm{a}$ shows the relationship between the observed and predicted values of weight loss of grapes for all experimental data. Figure $2 b$ shows the distribution of the residuals obtained from Equation 3 and Figure $2 \mathrm{c}$ shows residuals versus predicted values of weight.

Therefore, the model described the water loss process adequately as shown by the $\mathrm{R}^{2}$ and by the good agreement between observed and predicted mass of grapes (Figure 2a). The normal distribution of the residuals (Figure $2 \mathrm{~b}$ ) was quantified by the Kolgomorov-Smirnov test $(\mathrm{d}=0.086)$, indicating that the trend was not biased. The observed versus predicted plot (Figure 2c) indicates that the residuals are very close to the expected normal value.

\subsection{Validation experiments}

The model was validated by evaluating the model predictions for table grapes weight loss, as described in section Validation of the model. Figure 3 shows the good agreement between experimental and predicted values. Each point of the experimental data curve corresponds to the average of three samples. The weight loss of the grapes followed approximately a linear profile during the monitored period. However, the rate of the weight loss changed proportionally to the fluctuations of the refrigerator temperatures. In the first validation experiment (Figure $3 \mathrm{a}$ ) temperature ranged from $\sim 3{ }^{\circ} \mathrm{C}$ to $\sim 17^{\circ} \mathrm{C}$, meanwhile in the second one (Figure $3 \mathrm{~b}$ ) temperature ranged from $\sim-3{ }^{\circ} \mathrm{C}$ to $\sim 18{ }^{\circ} \mathrm{C}$.

The goodness of fit for each validation test was determined by calculation of the mean relative percentage deviation modulus (E) as proposed by McLaughlin and O'Beirne (1999). The Evalues were 0.28 and $1.10 \%$ for Figure $3 \mathrm{a}$ and Figure $3 \mathrm{~b}$, respectively. Larger amplitudes in the temperature fluctuation profile, as shown by Figure 3b, seem to increase the gap between model predictions and observed data $\left(\mathrm{R}^{2}\right.$ value was 0.995 and 0.577 for Figure 3a and Figure 3b, respectively).

The results above indicate that the developed model approach was adequate, confirming its predictive ability. Although previous publication has demonstrated that berries, the whole stem and grape stem parts have different dehydration kinetics (Ngcobo et al., 2013), the modelling approach presented

Table 2. Estimated parameters of the mathematical model (Equation 3), where $k_{i}$ is the mass transfer coefficient $\left(\mathrm{g} \mathrm{h}^{-1} \mathrm{~kg}^{-1}\right)$ and $a$ is the overall effect of temperature coefficient $\left({ }^{\circ} \mathrm{C}^{-1}\right)$, standard error (SE) of the estimation and determination coefficient $\left(\mathrm{R}^{2}\right)$.

\begin{tabular}{ccc}
\hline$k_{i}(\mathrm{SE})$ & $a(\mathrm{SE})$ & $\mathrm{R}^{2}$ \\
\hline $0.474(0.007)$ & $0.213(0.008)$ & 0.974 \\
\hline
\end{tabular}

here considers the whole cluster as homogeneous structure, setting a single constant value for the process. Therefore, this simplification made about the cluster structure appears to represent adequately the overall water loss process in dynamic temperature conditions.

\subsection{Effect of cooling delays on subsequent transpiration rates}

Figure 4 shows that transpiration rates $\left(T R ; \mathrm{g} \mathrm{kg}^{-1} \mathrm{~h}^{-1}\right)$ estimated in subsequent continuous temperature treatment were not significantly influenced by prior exposure to environmental temperatures. The transpiration rates, calculated with Equation 1, for cooling delay treatments were similar to those of continuous refrigeration. Tukey test at a significance level of 0.05 indicates that does not exist significant difference among the transpiration rates of all treatments. It suggests that effects of temperature on transpiration rates are not dependent on prior events in the cold chain for this cultivar of grapes. However, delayed
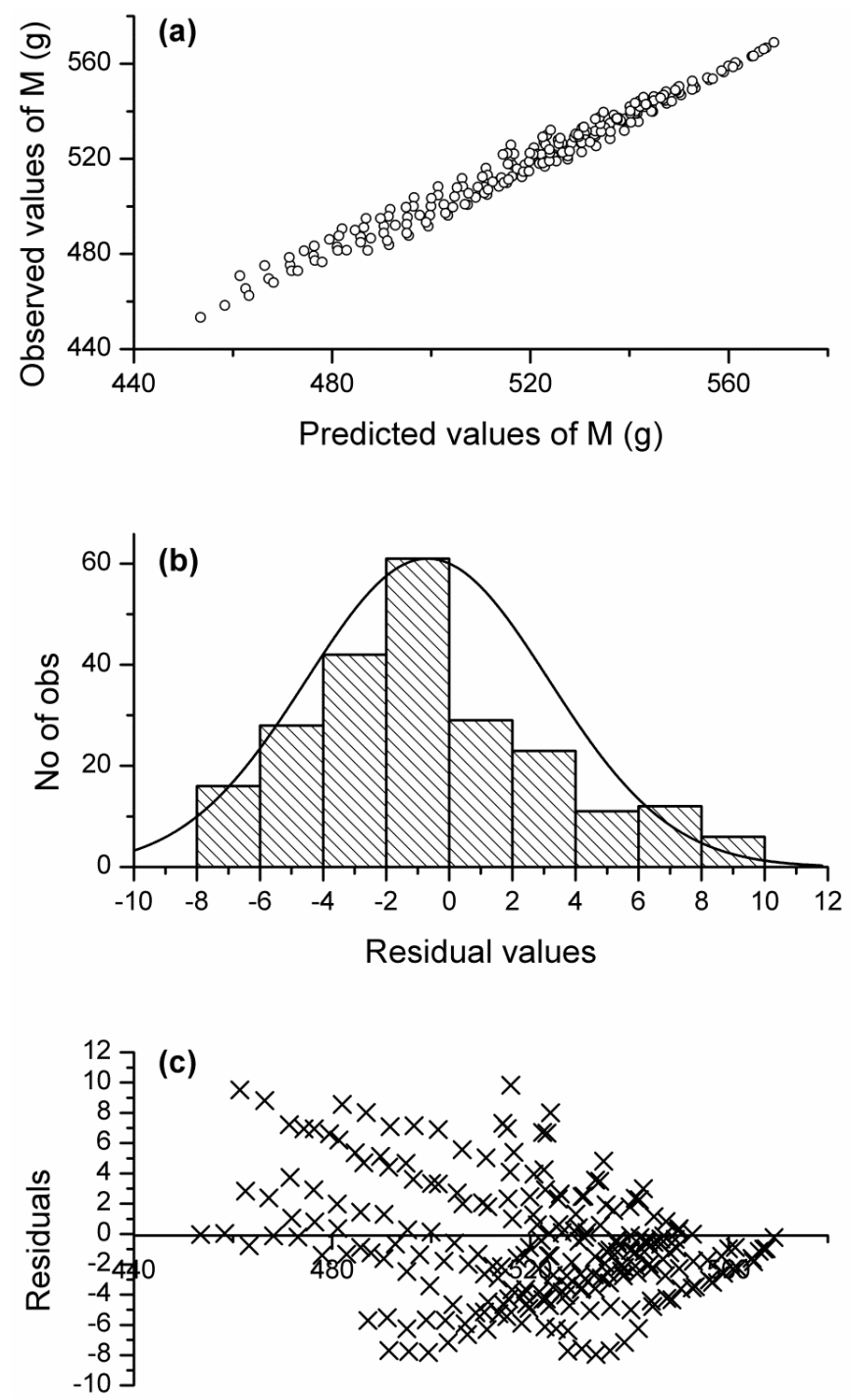

Figure 2. Relationship between observed and predicted weight of grapes for all the experimental data obtained (a). Frequency distribution of the residual values (b). Predicted versus residual values (c). 

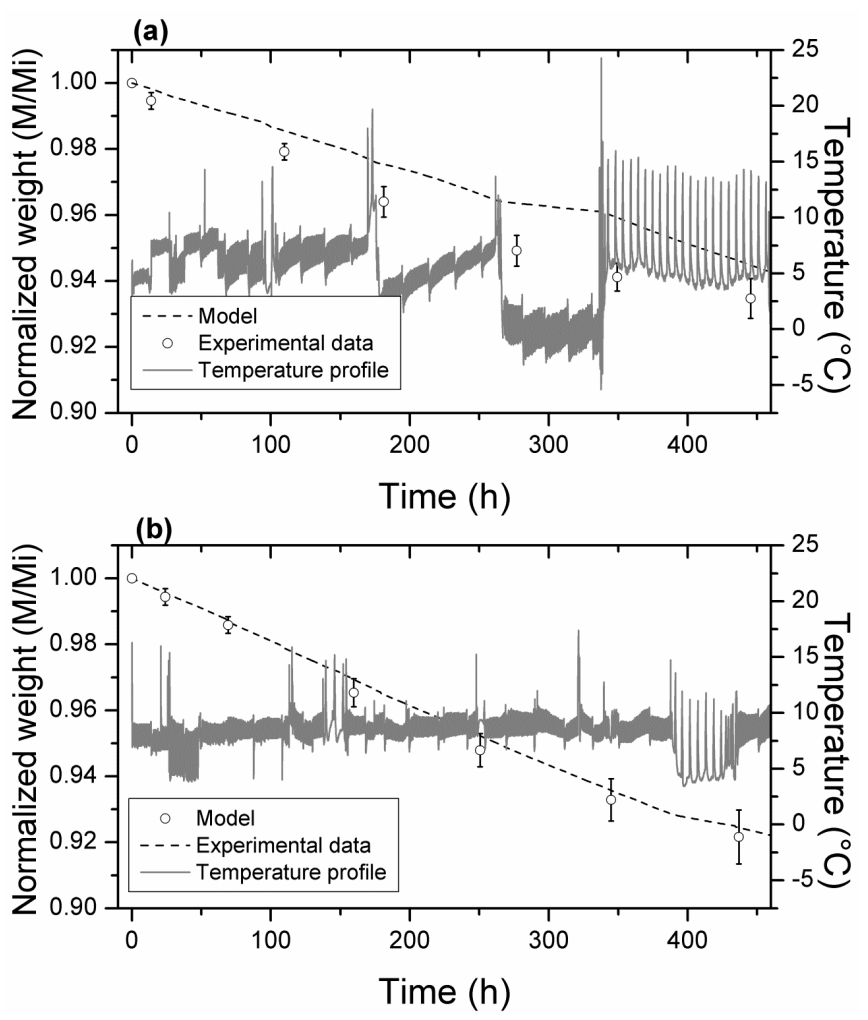

Figure 3. Relationship between the model predictions (dotted line) and the experimental data (symbols) for changes in mass of table grapes stored at common refrigerators. The values $(\mathrm{M})$ were normalized with respect to the initial weight of grapes $\left(M_{i}\right)$. The non-isothermal temperature historic (continuous line) is registered in right side $\mathrm{Y}$ axis. First validation experiment with deviation modulus of $0.28 \%$ (a). Second validation experiment with deviation modulus of $1.10 \%$ (b).

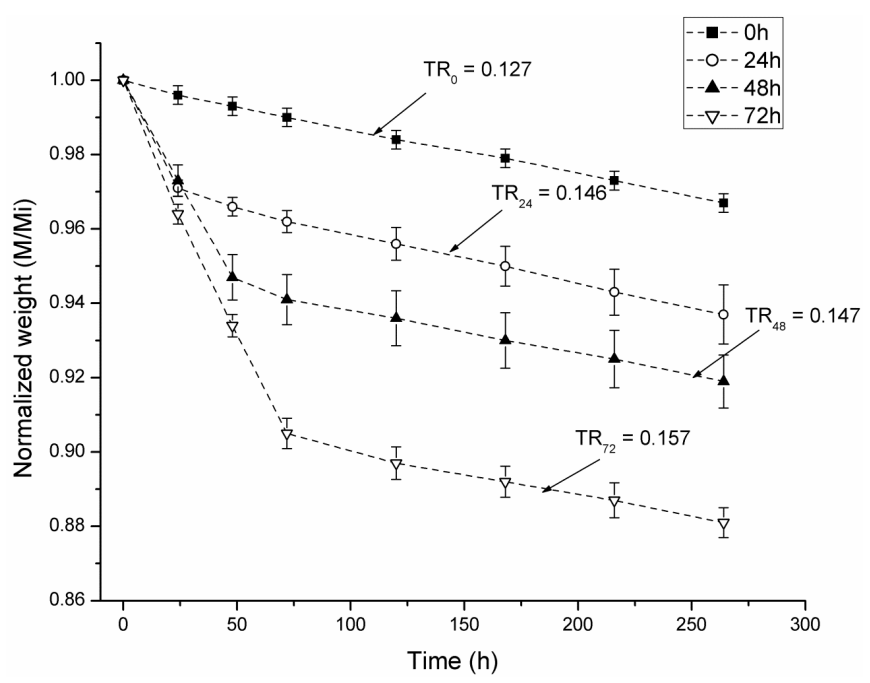

Figure 4. Transpiration rates (TR; $\left.\mathrm{g} \mathrm{h}^{-1} \mathrm{~kg}^{-1}\right)$ and normalized weight with respect to the initial weight $\left(\mathrm{M} / \mathrm{M}_{\mathrm{i}}\right)$ of table grapes exposed to cooling delays periods $(24,48$ and $72 \mathrm{~h}$ ) and continuous refrigeration $(0 \mathrm{~h})$. Each point of the curve (symbols) corresponds to the average of three samples. Standard deviations are shown in error bars. cooling significantly reduced the mass of the table grapes clusters in comparison with those maintained under continuous refrigeration. Consequently, the overall quality decay of grapes exposed to cooling delay was accelerated while its visual quality deteriorated rapidly, reinforcing the importance of stringent cold chain management for table grapes.

These presented results indicate that the modified equation Equation 4 has potential to describe the influence of temperature perturbation during postharvest handling. Thus, this model can be used to estimate the weight loss as consequence of interruptions in the cold chain, as well as to minimize losses during the logistical operations. This study is, to the best of our knowledge, pioneer to measure weight loss curves for table grapes from cooling delay treatments.

\section{Conclusion}

Transpiration rates of table grapes packed in PET punnets were found to be in the range of 0.104 to $0.201 \mathrm{~g} \mathrm{~kg}^{-1} \mathrm{~h}^{-1}$. A mathematical model developed on the basis of Fick's law of diffusion considering the effect of temperature and RH, yielded adequate description of mass loss of table grapes during storage at different combinations of temperature and RH. A modification in the model was proposed and tested for non-isothermal conditions situations. The results obtained in the validation experiments indicate that the model can provide satisfactory predictions for table grapes weight loss, and describe adequately the fruit behavior in variable temperature and $\mathrm{RH}$ conditions. A proposed study for the subsequent transpiration rates for table grapes submitted to cooling delays revealed that the temperature dependency of the weight loss was not associated to prior events in the cold chain, in this case the exposure to unfavorable temperatures. These results reinforce that the proposed model has the capacity to describe the influence of temperature perturbation during postharvest chain. Therefore, the model approach is useful to understand the evolution of water loss of table grapes with temperature, $\mathrm{RH}$, and time.

\section{References}

Alferez, F., Alfred, L., \& Burns, J. K. (2005). Low relative humidity at harvest and before storage at high humidity influence the severity of postharvest peel pitting in citrus. Journal of the American Society for Horticultural Science, 130(2), 225-231.

Amodio, M. L., Derossi, A., \& Colelli, G. (2013). Modelling sensorial and nutritional changes to better define quality and shelf life of fresh-cut melons. Journal of Agricultural Engineering, 43(4), 38-45. http://dx.doi.org/10.4081/jae.2013.e6.

Amodio, M. L., Derossi, A., Mastrandrea, L., \& Colelli, G. (2015). A study of the estimated shelf life of fresh rocket using a non-linear model. Journal of Food Engineering, 150, 19-28. http://dx.doi. org/10.1016/j.jfoodeng.2014.10.030.

Ben-Yehoshua, S. (1987). Transpiration, sater stress, and gas exchange. In J. Weichmann (Ed.), Postharvest physiology of vegetables (Food Science and Technology, Vol. 24, pp. 113-170). New York: Marcel Dekker Inc.

Crisosto, C. H., \& Mitchell, F. G. (2002). Table grapes. In A. A. Kader (Ed.), Postharvest technology of horticultural crops (3rd ed., pp. 357- 
363). Oakland: University of California Agricultural and Natural Resources.

Crisosto, C. H., Smilanick, J. L., \& Dokoozlian, N. K. (2001). Table grapes suffer water loss, stem browning during cooling delays. California Agriculture, 55(1), 39-42. http://dx.doi.org/10.3733/ca.v055n01p39.

Crisosto, C. H., Smilanick, J. L., Dokoozlian, N. K., \& Luvisi, D. A. (1994). Maintaining table grape post-harvest quality for long distant markets. In Proceedings of the International Symposium on Table Grape Production. Anaheim: American Society for Enology and Viticulture. pp. 195-199. Retrieved from http://ucce.ucdavis.edu/ files/datastore/234-335.pdf

Fourie, J. F. (2008). Harvesting, handling and storage of table grapes (with focus on pre- and post-harvest pathological aspects). Acta Horticulturae, (785), 421-424. http://dx.doi.org/10.17660/ ActaHortic.2008.785.54.

Gogou, E., Katsaros, G., Derens, E., Alvarez, G., \& Taoukis, P. S. (2015). Cold chain database development and application as a tool for the cold chain management and food quality evaluation. International Journal of Refrigeration, 52, 109-121. http://dx.doi.org/10.1016/j. ijrefrig.2015.01.019.

Gwanpua, S. G., Verlinden, B. E., Hertog, M. L. A. T. M., Bulens, I., Van de Poel, B., Van Impe, J., Nicolaï, B. M., \& Geeraerd, A. H. (2012). Kinetic modeling of firmness breakdown in "braeburn" apples stored under different controlled atmosphere conditions. Postharvest Biology and Technology, 67, 68-74. http://dx.doi.org/10.1016/j. postharvbio.2011.12.010.

Gwanpua, S. G., Verlinden, B. E., Hertog, M. L. A. T. M., Van Impe, J., Nicolai, B. M., \& Geeraerd, A. H. (2013). Towards flexible management of postharvest variation in fruit firmness of three apple cultivars. Postharvest Biology and Technology, 85, 18-29. http:// dx.doi.org/10.1016/j.postharvbio.2013.04.015.

Hertog, M. L. A. T. M. (2002). The impact of biological variation on postharvest population dynamics. Postharvest Biology and Technology, 26(3), 253-263. http://dx.doi.org/10.1016/S0925-5214(02)00044-3.

Hertog, M. L. A. T. M., Ben-Arie, R., Róth, E., \& Nicolaï, B. M. (2004a). Humidity and temperature effects on invasive and non-invasive firmness measures. Postharvest Biology and Technology, 33(1), 79-91. http://dx.doi.org/10.1016/j.postharvbio.2004.01.005.

Hertog, M. L. A. T. M., Lammertyn, J., Desmet, M., Scheerlinck, N., \& Nicolai, B. M. (2004b). The impact of biological variation on postharvest behaviour of tomato fruit. Postharvest Biology and Technology, 34(3), 271-284. http://dx.doi.org/10.1016/j.postharvbio.2004.05.014.

Hertog, M. L. A. T. M., Nicholson, S. E., \& Jeffery, P. B. (2004c). The effect of modified atmospheres on the rate of firmness change of "hayward" kiwifruit. Postharvest Biology and Technology, 31(3), 251261. http://dx.doi.org/10.1016/j.postharvbio.2003.09.005.

Hertog, M. L. A. T. M., Vollebregt, M., Unzueta, I., Hoofman, R. J. O. M., \& Lammertyn, J. (2015). From sensor output to improved product quality. Acta Horticulturae, 1091(1091), 165-173. http:// dx.doi.org/10.17660/ActaHortic.2015.1091.20.

James, S. J., Evans, J., \& James, C. (2008). A review of the performance of domestic refrigerators. Journal of Food Engineering, 87(1), 2-10. http://dx.doi.org/10.1016/j.jfoodeng.2007.03.032.

Johnston, J. W., Hewett, E. W., \& Hertog, M. L. A. T. M. (2005). Apple (Malus domestica) softening in the postharvest coolchain: effects of delayed cooling and shelf-life temperatures. New Zealand Journal of Crop and Horticultural Science, 33(3), 283-292. http://dx.doi.or g/10.1080/01140671.2005.9514361.

Kader, A. A. (2002). Postharvest biology and technology: an overview. In A. A. Kader (Ed.), Postharvest technology of horticultural crops (3rd ed., pp. 39-48). Oakland: University of California Agricultural and Natural Resources.

Labuza, T. P. (1982). Shelf-life dating of foods (1st ed.). Westport: Food \& Nutrition Press Inc.

Laguerre, O., Derens, E., \& Palagos, B. (2002). Study of domestic refrigerator temperature and analysis of factors affecting temperature: a french survey. International Journal of Refrigeration, 25(5), 653-659. http://dx.doi.org/10.1016/S0140-7007(01)00047-0.

Leonardi, C., Baille, A., \& Guichard, S. (1999). Effects of fruit characteristics and climatic conditions on tomato transpiration in a greenhouse. The Journal of Horticultural Science \& Biotechnology, 74(6), 748-756. http://dx.doi.org/10.1080/14620316.1999.11511183.

Lichter, A., Kaplunov, T., Zutahy, Y., Daus, A., Alchanatis, V., Ostrovsky, V., \& Lurie, S. (2011). Physical and visual properties of grape rachis as affected by water vapor pressure deficit. Postharvest Biology and Technology, 59(1), 25-33. http://dx.doi.org/10.1016/j. postharvbio.2010.07.009.

Maguire, K. M., Banks, N. H., \& Lang, A. (1999). Sources of variation in water vapour permeance of apple fruit. Postharvest Biology and Technology, 17(1), 11-17. http://dx.doi.org/10.1016/S09255214(99)00034-4.

Maguire, K. M., Banks, N. H., \& Opara, L. U. (2001). Factors affecting weight loss of apples. In J. Janick (Ed.), Horticultural reviews (Vol. 25, pp. 197-234). Oxford: John Wiley \& Sons Inc.

Mahajan, P. V., Oliveira, F. A. R., \& Macedo, I. (2008). Effect of temperature and humidity on the transpiration rate of the whole mushrooms. Journal of Food Engineering, 84(2), 281-288. http:// dx.doi.org/10.1016/j.jfoodeng.2007.05.021.

McLaughlin, C. P., \& O’Beirne, D. (1999). Respiration rate of a dry coleslaw mix affected by storage temperature and respiratory gas concentrations. Journal of Food Science, 64(1), 116-119. http://dx.doi. org/10.1111/j.1365-2621.1999.tb09872.x.

Mencarelli, F., Bellincontro, A., \& DiRenzo, G. (2005). Grape: postharvest operations. Rome: FAO. Retrieved from http://www.fao. org/3/a-av004e.pdf

Nelson, K. E. (1978). Pre-cooling - its significance to the market quality of table grapes. International Journal of Refrigeration, 1(4), 207-215. http://dx.doi.org/10.1016/0140-7007(78)90114-7.

Ngcobo, M. E. K., Pathare, P. B., Delele, M. A., Chen, L., \& Opara, U. L. (2013). Moisture diffusivity of table grape stems during low temperature storage conditions. Biosystems Engineering, 115(3), 346-353. http://dx.doi.org/10.1016/j.biosystemseng.2013.03.013.

Nobel, P. S. (2005). Water. In Physicochemical and environmental plant physiology (3rd, Vol. 1, pp. 45-98). Netherlands: Elsevier.

Nunes, M. C. N., Emond, J. P., Rauth, M., Dea, S., \& Chau, K. V. (2009). Environmental conditions encountered during typical consumer retail display affect fruit and vegetable quality and waste. Postharvest Biology and Technology, 51(2), 232-241. http://dx.doi.org/10.1016/j. postharvbio.2008.07.016.

Schouten, R. E., Huijben, T. P. M., Tijskens, L. M. M., \& Van Kooten, O. (2007). Modelling quality attributes of truss tomatoes: linking colour and firmness maturity. Postharvest Biology and Technology, 45(3), 298-306. http://dx.doi.org/10.1016/j.postharvbio.2007.03.011.

Schouten, R. E., Natalini, A., Tijskens, L. M. M., Woltering, E. J., \& Van Kooten, O. (2010). Modelling the firmness behaviour of cut tomatoes. Postharvest Biology and Technology, 57(1), 44-51. http:// dx.doi.org/10.1016/j.postharvbio.2010.02.001.

Shamaila, M. (2005). Water and its relation to fresh produce. In D. Ukuku, S. Imam, \& O. Lamikanra (Eds.), Produce degradation 
pathways and prevention (pp. 267-291). Boca Raton: CRC Press. Retrieved from http://www.crcnetbase.com/isbn/978-0-8493-1902-0

Shibairo, S. I., Upadhyaya, M. K., \& Toivonen, P. M. (2002). Changes in water potential, osmotic potential, and tissue electrolyte leakage during mass loss in carrots stored under different conditions. Scientia Horticulturae, 95(1-2), 13-21. http://dx.doi.org/10.1016/ S0304-4238(02)00034-1.

Smedt, V., Barreiro, P., Verlinden, B., Veraverbeke, E., Baerdemaeker, J., \& Nicolai, B. (2002). A mathematical model for the development of mealiness in apples. Postharvest Biology and Technology, 25(3), 273-291. http://dx.doi.org/10.1016/S0925-5214(01)00185-5.

Sousa-Gallagher, M. J., Mahajan, P. V., \& Mezdad, T. (2013). Engineering packaging design accounting for transpiration rate: model development and validation with strawberries. Journal of Food Engineering, 119(2), 370-376. http://dx.doi.org/10.1016/j.jfoodeng.2013.05.041.

Statsoft. (2007). Statistica: data analysis software system. Version 7.0. Tulsa: Statsoft. Retrieved from www.statsoft.com
Thompson, J. F. (2002). Psychrometrics and pershable commodities. In A. A. Kader (Ed.), Postharvest technology of horticultural crops (3rd ed., pp. 129-134). Oakland: University of California Agricultural and Natural Resources.

Tijskens, L. M. M., \& Schouten, R. E. (2009). Modeling quality attributes and quality related product properties. In W. J. Florkowski, R. L. Shewfelt, B. Brueckner, \& S. E. Prussia (Eds.), Postharvest handling (pp. 411-448). Netherlands: Elsevier.

Tijskens, L. M. M., Jacob, S., Schouten, R. E., Fernández-Trujillo, J. P., Dos-Santos, N., Vangdal, E., Pagán, E., \& Pérez Pastor, A. (2010). Water loss in horticultural products - modelling, data analysis and theoretical considerations. Acta Horticulturae, (858), 465-471. http:// dx.doi.org/10.17660/ActaHortic.2010.858.71.

Veraverbeke, E. A., Verboven, P., Scheerlinck, N., Lan Hoang, M., \& Nicolaï, B. M. (2003). Determination of the diffusion coefficient of tissue, cuticle, cutin and wax of apple. Journal of Food Engineering, 58(3), 285-294. http://dx.doi.org/10.1016/S0260-8774(02)00387-4. 